\title{
Silver-Catalyzed Dehydrogenative Synthesis of Carboxylic Acids from Primary Alcohols
}

\section{Ghalehshahi, Hajar Golshadi; Madsen, Robert}

\section{Published in:}

Chemistry - A European Journal

Link to article, DOI:

10.1002/chem.201702420

Publication date:

2017

Document Version

Peer reviewed version

Link back to DTU Orbit

Citation (APA):

Ghalehshahi, H. G., \& Madsen, R. (2017). Silver-Catalyzed Dehydrogenative Synthesis of Carboxylic Acids from Primary Alcohols. Chemistry - A European Journal, 23(49), 11920-11926.

https://doi.org/10.1002/chem.201702420

\section{General rights}

Copyright and moral rights for the publications made accessible in the public portal are retained by the authors and/or other copyright owners and it is a condition of accessing publications that users recognise and abide by the legal requirements associated with these rights.

- Users may download and print one copy of any publication from the public portal for the purpose of private study or research.

- You may not further distribute the material or use it for any profit-making activity or commercial gain

- You may freely distribute the URL identifying the publication in the public portal

If you believe that this document breaches copyright please contact us providing details, and we will remove access to the work immediately and investigate your claim. 


\title{
Silver-Catalyzed Dehydrogenative Synthesis of Carboxylic Acids from Primary Alcohols
}

\author{
Hajar Golshadi Ghalehshahi ${ }^{[a, b]}$ and Robert Madsen*[a]
}

\begin{abstract}
A simple silver-catalyzed protocol has been developed for the acceptorless dehydrogenation of primary alcohols into carboxylic acids and hydrogen gas. The procedure uses $2.5 \% \mathrm{Ag}_{2} \mathrm{CO}_{3}$ and 2.5 - 3 equiv. of $\mathrm{KOH}$ in refluxing mesitylene to afford the potassium carboxylate which is then converted into the acid with $\mathrm{HCl}$. The reaction can be applied to a variety of benzylic and aliphatic primary alcohols with alkyl and ether substituents, and in some cases halide, olefin and ester functionalities are also compatible with the reaction conditions. The dehydrogenation is believed to be catalyzed by silver nanoparticles that are formed in situ under the reaction conditions.
\end{abstract}

\section{Introduction}

Chemical reactions which are initiated by the dehydrogenation of an alcohol have received much attention for more than a decade. ${ }^{[1]}$ In these transformations hydrogen gas is liberated from the alcohol and no stoichiometric oxidant or hydrogen acceptor is necessary. The most effective metal catalysts have been a variety of ruthenium and iridium complexes which has made it possible to prepare ketones, imines, amides and esters directly from alcohols (and amines). ${ }^{[1]}$

In 2013 the conversion of a primary alcohol to the carboxylic acid and hydrogen gas was presented for the first time catalyzed by a ruthenium PNN pincer complex. ${ }^{[2]}$ Since then the transformation has also been achieved with a several other ruthenium complexes containing PNP pincer, ${ }^{[3]} \mathrm{NNN}$ pincer, ${ }^{[4]} \mathrm{N}$ heterocyclic carbene ${ }^{[5]}$ and 2,2'-bipyridine type ${ }^{[6]}$ ligands. In addition, a binuclear rhodium complex with two terpyridine ligands ${ }^{[7]}$ and palladium on carbon ${ }^{[8]}$ have been used to catalyze the dehydrogenation to carboxylic acids where a reduced pressure was necessary with the palladium catalyst to remove the liberated hydrogen gas. In all cases, a catalyst loading between $0.1 \%$ and $5 \%$ was employed and the reactions were carried out at elevated temperature with water or toluene as the solvent. ${ }^{2-8}$ In addition, a stoichiometric amount of a base was added such as $\mathrm{NaOH}, \mathrm{KOH}, \mathrm{CsOH}$ or $\mathrm{Cs}_{2} \mathrm{CO}_{3}$ giving rise to the alkali metal salt of the carboxylic acid as the immediate product. The addition of the base also makes the overall transformation

[a] H. G. Ghalehshahi, Prof. Dr. R. Madsen

Department of Chemistry

Technical University of Denmark

2800 Kgs. Lyngby (Denmark)

E-mail: rm@kemi.dtu.dk

[b] H. G. Ghalehshahi

Current address: Department of Chemistry

K. N. Toosi University of Technology

P. O. Box 15875, 4416 Tehran (Iran)

Supporting information for this article is given via a link at the end of the document. energetically more favored and prevents deactivation of the catalyst by the carboxylic acid. We have developed the ruthenium $\mathrm{N}$-heterocyclic carbene complex $\left[\operatorname{RuCl}_{2}(\operatorname{IPr})(p-\right.$ cymene)] for the synthesis of carboxylic acids ${ }^{[5]}$ and have also used the same complex for preparation of imines, amides and esters from primary alcohols. ${ }^{[9]}$

So far the acceptorless dehydrogenation of a primary alcohol to the carboxylic acid has only been achieved with a metal catalyst from the platinum group metals. However, there is a significant interest in the field to develop cheaper catalysts for these dehydrogenative transformations with alcohols. This has been demonstrated in the synthesis of imines from alcohols and amines where manganese, cobalt, iron, copper and silver catalysts have been shown to perform the reaction in the absence of an acceptor. ${ }^{[10]}$ The silver-catalyzed imine synthesis was performed with silver nanoparticles deposited on an alumina support. ${ }^{[10 e]} \mathrm{Ag} / \mathrm{Al}_{2} \mathrm{O}_{3}$ has also been shown to catalyze the formation of amides from alcohols and amines, and the dehydrogenation of alcohols into aldehydes and ketones. ${ }^{[11]}$ In addition, silver nanoparticles on either $\mathrm{ZnO}$, silica-coated ferrite or hydrotalcite have been shown to catalyze the production of aldehydes and ketones from alcohols. ${ }^{[12]}$ Thus, silver(0) catalysts constitutes and interesting alternative to the platinum group metals for dehydrogenative transformations with alcohols.

Herein, we describe the development of the first silvercatalyzed acceptorless dehydrogenation of primary alcohols into carboxylic acids.

\section{Results and Discussion}

The dehydrogenation was discovered by serendipity when attempting to perform the same reaction with a manganese catalyst. Manganese-catalyzed dehydrogenation of alcohols was recently presented for the first time, ${ }^{[10 a]}$ but so far only manganese(I) species stabilized by PNP pincer and carbon monoxide ligands have been employed as catalysts. ${ }^{[13]} \mathrm{We}$ decided to perform several experiments with more simple systems and tested a variety of manganese sources and additives as catalysts. Benzyl alcohol was selected as the substrate and the reactions were performed by stirring the catalyst with 2.5 equiv. of $\mathrm{KOH}$ powder in mesitylene solution for 10 min followed by addition of the alcohol and heating the mixture to reflux. Interestingly, the best results were obtained in the presence of a silver salt (Table 1, entries 1 - 7). Grey particles were formed during the reactions, but the role of the silver source was not immediately clear. However, the transformation also proceeded in the absence of the manganese salt (entries $8-12$ ) which gave rise to speculations about silver nanoparticles being responsible for the dehydrogenation. ${ }^{[14]}$ Silver nanoparticles are usually stabilized by a heterogeneous 
support, but can also be formed in solution under basic conditions where the particles are stabilized by the absorption of hydroxide at the surface. ${ }^{[15]}$ In addition, alcohols are known to serve as reducing agents for the formation of silver nanoparticles from silver salts. ${ }^{[16]}$ The reaction with $\mathrm{AgBF}_{4}$ was also tested in xylene, toluene, dioxane and tert-amyl alcohol at reflux, but only $15-20 \%$ yield was obtained in these solvents while no conversion occurred in water (results not shown). The same result was observed when $\mathrm{KOH}$ was replaced with $\mathrm{LiOH}$ (entry 13).

Table 1. Optimization of benzyl alcohol dehydrogenation.

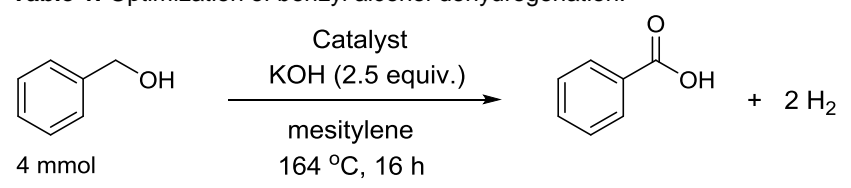

\begin{tabular}{|c|c|c|}
\hline Entry & Catalyst & Yield $[\%]^{[a]}$ \\
\hline 1 & $2.5 \% \mathrm{MnBr}_{2}$ & 0 \\
\hline 2 & $10 \% \mathrm{CpMn}(\mathrm{CO})_{3}$ & 19 \\
\hline 3 & $10 \% \mathrm{MnCl}_{2}, 10 \% \mathrm{Zn}$ powder & 10 \\
\hline 4 & $10 \% \mathrm{Mn}$ powder, $2.5 \% \mathrm{Ag}_{2} \mathrm{CO}_{3}$ & 32 \\
\hline 5 & $2.5 \% \mathrm{MnBr}_{2}, 2.5 \% \mathrm{Ag}_{2} \mathrm{O}$ & 47 \\
\hline 6 & $2.5 \% \mathrm{Mn}_{2}(\mathrm{CO})_{10}, 2.5 \% \mathrm{Ag}_{2} \mathrm{CO}_{3}$ & 67 \\
\hline 7 & $2.5 \% \mathrm{MnCl}_{2}, 2.5 \% \mathrm{Ag}_{2} \mathrm{CO}_{3}$ & 74 \\
\hline 8 & $2.5 \% \mathrm{Ag}_{2} \mathrm{CO}_{3}$ & 81 \\
\hline 9 & $2.5 \% \mathrm{Ag}_{2} \mathrm{O}$ & 78 \\
\hline 10 & $5 \% \mathrm{AgBF}_{4}$ & 73 \\
\hline 11 & $5 \% \mathrm{AgNO}_{3}$ & 66 \\
\hline 12 & $5 \% \mathrm{AgCl}$ & 48 \\
\hline $13^{[\mathrm{b}]}$ & $2.5 \% \mathrm{Ag}_{2} \mathrm{CO}_{3}$ & 0 \\
\hline 14 & $2.5 \% \mathrm{Ag}_{2} \mathrm{CO}_{3}, 2.5 \% \mathrm{MnCO}_{3}$ & 81 \\
\hline 15 & $2.5 \% \mathrm{Ag}_{2} \mathrm{CO}_{3}, 2.5 \% \mathrm{MnBr}_{2}$ & 98 \\
\hline $16^{[c]}$ & $2.5 \% \mathrm{Ag}_{2} \mathrm{CO}_{3}, 2.5 \% \mathrm{MnBr}_{2}$ & 86 \\
\hline $17^{[\mathrm{d}]}$ & $2.5 \% \mathrm{Ag}_{2} \mathrm{CO}_{3}, 2.5 \% \mathrm{MnBr}_{2}$ & 73 \\
\hline 18 & $2.5 \% \mathrm{Ag}_{2} \mathrm{CO}_{3}, 2.5 \% \mathrm{MnBr}_{2}, \mathrm{PVP}$ & 99 \\
\hline
\end{tabular}

[a] GC yield. [b] With $\mathrm{LiOH}$ instead of $\mathrm{KOH}$. [c] With 2 equiv. of $\mathrm{KOH}$. [d] With 1.6 equiv. of $\mathrm{KOH}$.

$\mathrm{Ag}_{2} \mathrm{CO}_{3}$ gave the highest yield among the different silver sources. If nanoparticles are the reactive catalyst in the reaction, the formation and stability of these species will influence the yield. This made us test manganese sources again (entries $14-$ 17) since the manganese salt may affect the nanoparticle formation. With $\mathrm{MnBr}_{2}$ an improvement in the yield was obtained (entry 15) although the result was not fully reproducible in some cases. A small amount of a heterogeneous support was therefore added and polyvinylpyrrolidone (PVP) is a well-known dispersant for silver nanoparticles. ${ }^{[16]}$ Under these conditions a near quantitative GC yield of benzoic acid could now be obtained consistently when repeating the reaction (entry 18). ${ }^{[17]}$ The base was also investigated again and the yield decreased slightly with lower amounts of $\mathrm{KOH}$ (entries 16 and 17).

We have previously established that the Cannizzaro reaction may be operating in these dehydrogenations of benzylic alcohols under basic conditions ${ }^{[5 a]}$ and this is also true for the silver-catalyzed protocol. Subjecting benzaldehyde to the optimized conditions in entry 18 led to rapid formation of a mixture of potassium benzoate and benzyl alcohol where the latter was slowly converted into the former over a period of $4 \mathrm{~h}$ (Figure 1). Benzaldehyde, though, was not quantified in this experiment due to co-elution with the solvent.

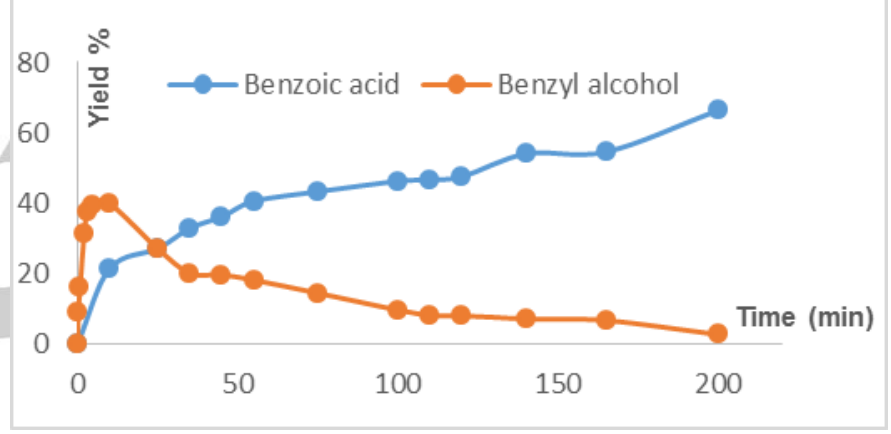

Figure 1. Dehydrogenation of benzaldehyde.

The evolution of hydrogen gas was measured under the optimized conditions in entry 18 and a total of $7.3 \mathrm{mmol}$ of $\mathrm{H}_{2}$ was collected after $7 \mathrm{~h}$ from the reaction with $4 \mathrm{mmol}$ of benzyl alcohol and $0.1 \mathrm{mmol}$ of $\mathrm{Ag}_{2} \mathrm{CO}_{3}$. The identity of the gas was established through a subsequent hydrogenation of an olefin. This proves that the transformation takes place by a dehydrogenation pathway where no stoichiometric oxidant is involved. The experiment in entry 18 was also repeated four times in the presence of $0.75 \mathrm{mmol}$ of liquid mercury which was added after $0,2,4$ and $6 \mathrm{~h}$, respectively. The four reactions gave $0 \%, 20 \%, 45 \%$ and $63 \%$ yield after $8 \mathrm{~h}$ and in all cases the dehydrogenation stopped immediately after the addition of mercury. This observation strongly indicates that silver nanoparticles are responsible for the dehydrogenation where the addition of mercury has led to the formation of an inactive amalgam at the surface of the heterogeneous catalyst. ${ }^{[18]}$

A common procedure for preparation of silver nanoparticles is the so-called polyol process where $\mathrm{AgNO}_{3}$ is reacted with ethylene glycol in the presence of PVP. ${ }^{[16 a, c]}$ Therefore, an experiment was also performed where $\mathrm{AgNO}_{3}$ and PVP were stirred in ethylene glycol solution at $120^{\circ} \mathrm{C}$ for $1 \mathrm{~h}$ followed by centrifugation and removal of the solvent. ${ }^{[16 c]}$ To the residue was added $\mathrm{KOH}$, mesitylene and benzyl alcohol and the mixture was stirred at $165^{\circ} \mathrm{C}$ for $8 \mathrm{~h}$. This gave benzoic acid in $91 \% \mathrm{GC}$ yield 
which again points to silver nanoparticles as the responsible dehydrogenation catalyst.

Final confirmation was obtained by characterizing the morphology of the prepared nanoparticles by transmission electron microscopy (TEM). The reaction in Table 1 , entry 18 was stopped after $4 \mathrm{~h}$ and the solids were isolated by centrifugation, washed with acetone/water, and then dispersed in acetone. The TEM micrograph showed spherical and monodispersed silver nanoparticles and revealed a narrow particle size distribution with an average diameter of $15 \mathrm{~nm}$ (Figure 2).The crystalline nature of the nanoparticles was confirmed by X-ray diffraction (XRD) (Figure 3). Four characteristic peaks were observed at $38.3^{\circ}, 44.5^{\circ}, 64.7^{\circ}$ and $77.7^{\circ}$, respectively, corresponding to the (111), (200), (220) and (311) planes of the face centered cubic crystal structure of silver. ${ }^{[16 c]}$ An amorphous organic compound was also detected at $16-23^{\circ}$ which may correspond to PVP.

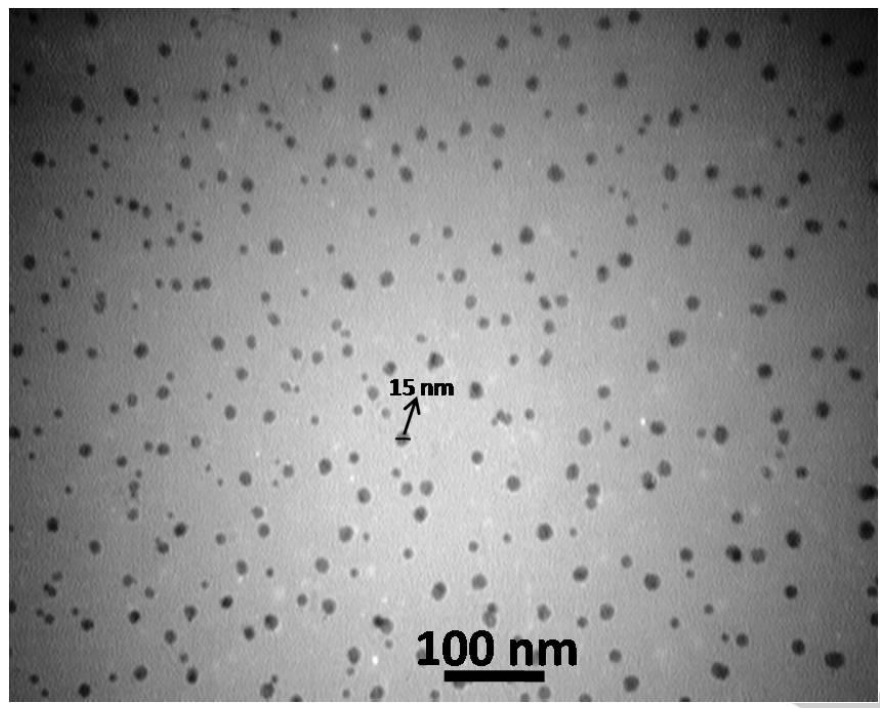

Figure 2. TEM micrograph of silver nanoparticles.

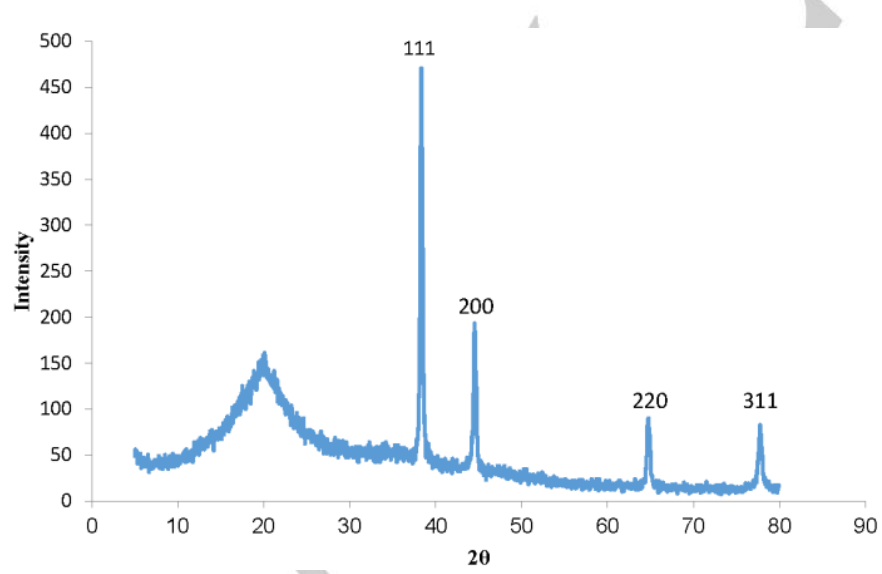

Figure 3. XRD pattern of silver nanoparticles.

The exact protocol for mixing the reactants and heating the mixture to reflux was important in order to achieve the near quantitative conversion in Table 1 , entry 18. A dark green suspension was obtained upon mixing $\mathrm{Ag}_{2} \mathrm{CO}_{3}, \mathrm{MnBr}_{2}$, PVP and $\mathrm{KOH}$ in mesitylene at room temperature and the mixture was first stirred for $5 \mathrm{~min}$ at room temperature and then heated to $50{ }^{\circ} \mathrm{C}$ over an additional $5 \mathrm{~min}$. At this temperature the alcohol was added to give a black suspension which was heated to $165^{\circ} \mathrm{C}$ at a rate of $5^{\circ} \mathrm{C} / \mathrm{min}$. While the temperature increased the mixture became colorless with some black particles visible. After about $1 \mathrm{~h}$ at $165^{\circ} \mathrm{C}$ the potassium salt of the carboxylic acid precipitated as a light brown solid. Adding the alcohol at $80^{\circ} \mathrm{C}$ or $100{ }^{\circ} \mathrm{C}$, on the other hand, gave very little or no conversion into the acid. A TEM micrograph was obtained after $4 \mathrm{~h}$ from the experiment where the alcohol was added at $100^{\circ} \mathrm{C}$. The image showed particles with different shapes and sizes, and where the diameter was larger than $500 \mathrm{~nm}$ (see supporting information). This clearly shows the involvement of the alcohol in the nanoparticle formation and the importance of adding the alcohol at $50{ }^{\circ} \mathrm{C}$ in order to obtain the distribution shown in Figure 2

With the optimized protocol available, the substrate scope and limitations could now be investigated in detail. First, a number of benzylic alcohols were converted into the corresponding acids using a reaction time of $8 \mathrm{~h}$ (Table 2). The isolated yield of benzoic acid was $92 \%$ (entry 1 ) while $p$-toluic acid was obtained in $85 \%$ yield (entry 2). With electronwithdrawing substituents in the para position the dehydrogenation occurred more rapidly. $p$ (Trifluoromethyl)benzyl alcohol gave the acid in near quantitative yield after only $2 \mathrm{~h}$ (entry 3 ). The shorter reaction time was also necessary to avoid partial defluorination since $p$ (difluoromethyl)benzoic acid was observed as a byproduct after $8 \mathrm{~h}$. In the same way p-chlorobenzyl alcohol afforded $p$ chlorobenzoic acid after $1.5 \mathrm{~h}$ at $150{ }^{\circ} \mathrm{C}$ (entry 4) while refluxing the mixture for $8 \mathrm{~h}$ gave complete dehalogenation to benzoic acid (entry 5). Small amounts of benzoic acid and benzyl alcohol were observed as byproducts under the milder conditions in entry 4. $p$-Bromobenzyl alcohol yielded only benzoic acid regardless of the reaction time (entry 6). Methyl $p$ (hydroxymethyl)benzoate furnished terephthalic acid monomethyl ester in $88 \%$ yield with the parent terephthalic acid as the main byproduct (entry 7 ). The relatively little hydrolysis of the ester was surprising since we observed complete ester hydrolysis in our previous attempt to dehydrogenate the same substrate with a ruthenium catalyst. ${ }^{[5 a]}$ The reason is most likely the faster conversion of methyl $p$-(hydroxymethyl)benzoate with the silver-catalyzed procedure leading to the insoluble potassium salt of terephthalic acid monomethyl ester. Ether- and phenyl-substituted benzyl alcohols gave the corresponding benzoic acids in $71-76 \%$ yield (entries $8-10$ ) while $p$ (methylthio)benzyl alcohol afforded the acid in a slightly lower yield (entry 11). Notably, no hydrogenolysis of the benzyl ether was observed in entry 9. Ortho-disubstituted 2,4,6trimethylbenzyl alcohol gave $58 \%$ yield of mesitoic acid due to incomplete conversion of the hindered alcohol (entry 12). oChlorobenzyl alcohol underwent complete dehalogenation (entry 13) while 2-naphthylmethanol furnished 2-naphthoic acid in $73 \%$ isolated yield (entry 14). p-Nitrobenzyl alcohol also underwent dehydrogenation to the carboxylic acid, but the reaction was 
accompanied by reduction of the nitro group to afford $p$ aminobenzoic acid. ${ }^{[19]}$ No attempt was made to optimize the reaction and to purify the product since the reduction requires 3 equiv. of $\mathrm{H}_{2}$ and only 2 equiv. are released in the dehydrogenation.

Table 2. Silver-catalyzed dehydrogenation of benzylic alcohols. ${ }^{[a]}$

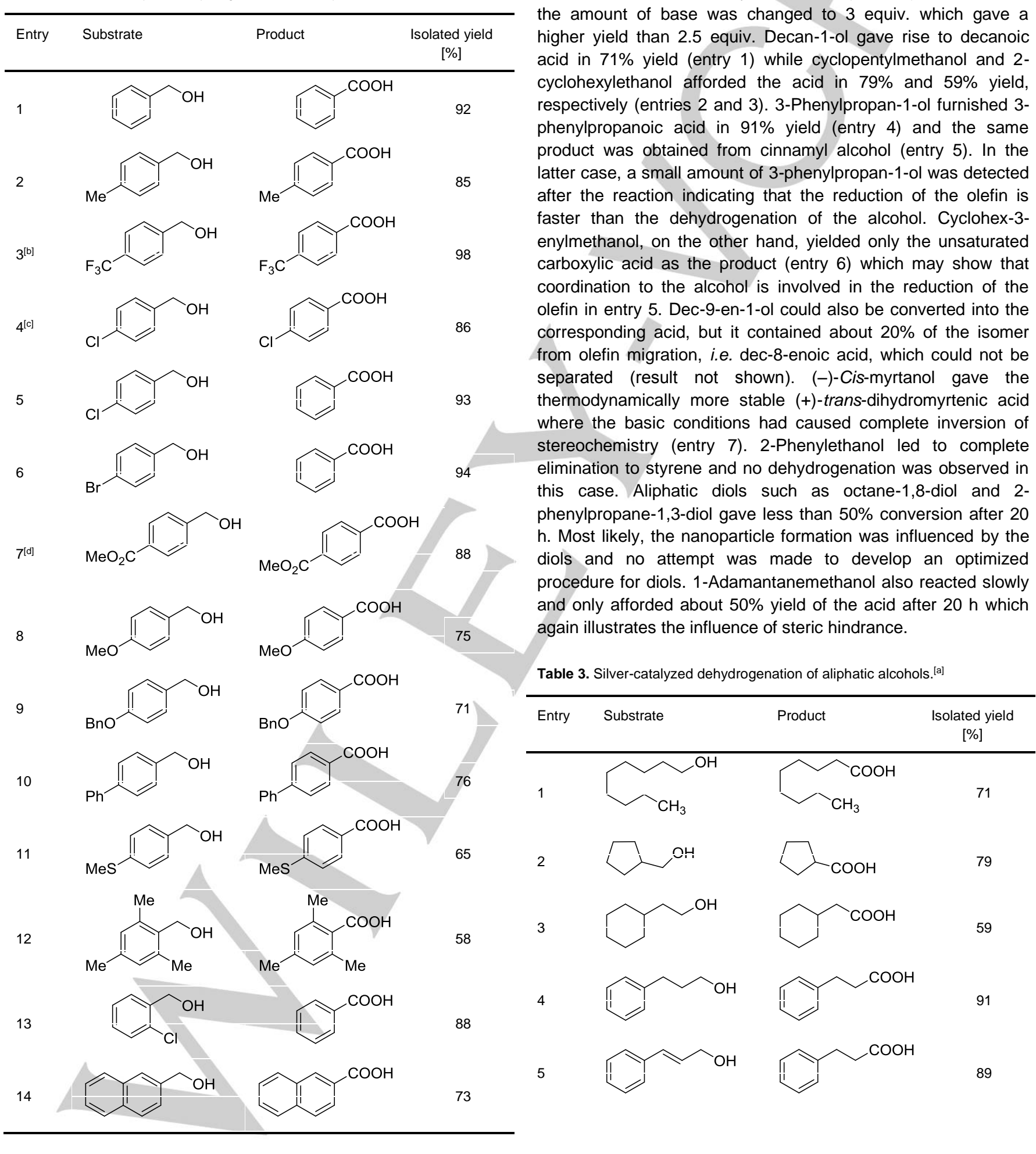

[a] Reaction conditions: Alcohol (4 mmol), $\mathrm{KOH}$ (10 mmol), $\mathrm{Ag}_{2} \mathrm{CO}_{3}(0.1 \mathrm{mmol})$, $\mathrm{MnBr}_{2}(0.1 \mathrm{mmol}), \mathrm{PVP}(15 \mathrm{mg})$, mesitylene, reflux, $8 \mathrm{~h}$, then aq. $\mathrm{HCl}$. [b] Reaction time $2 \mathrm{~h}$. [c] Reaction time $1.5 \mathrm{~h}$ at $150^{\circ} \mathrm{C}$. [d] Reaction time $4 \mathrm{~h}$.

The silver-catalyzed protocol could also be applied for dehydrogenation of aliphatic alcohols although a longer reaction time of $20 \mathrm{~h}$ was necessary in this case (Table 3). ${ }^{[20]}$ In addition, the amount of base was changed to 3 equiv. which gave a higher yield than 2.5 equiv. Decan-1-ol gave rise to decanoic acid in $71 \%$ yield (entry 1 ) while cyclopentylmethanol and 2 phenylpropanoic acid in $91 \%$ yield (entry 4) and the same after the reactio faster than the dehydrogenation of the alcohol. Cyclohex-3corresponding acid, but it contained about $20 \%$ of the isomer from olefin migration, i.e. dec-8-enoic acid, which could not be stereochemistry (entry 7). 2-Phenylethanol led to complete phenylpropane-1,3-diol gave less than $50 \%$ conversion after 20 h. Most likely, the nanoparticle formation was influenced by the procedure for diols. 1-Adamantanemethanol also reacted slowly and only afforded about $50 \%$ yield of the acid after $20 \mathrm{~h}$ which Table 3. Silver-catalyzed dehydrogenation of aliphatic alcohols. ${ }^{[a]}$ 
6<smiles>OCC1CC=CCC1</smiles><smiles>O=C(O)C1CC=CCC1</smiles>

7

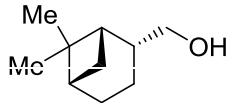

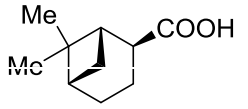

[a] Reaction conditions: Alcohol (4 mmol), $\mathrm{KOH}$ (12 mmol), $\mathrm{Ag}_{2} \mathrm{CO}_{3}(0.1 \mathrm{mmol})$ $\mathrm{MnBr}_{2}(0.1 \mathrm{mmol}), \mathrm{PVP}(15 \mathrm{mg})$, mesitylene, reflux, $20 \mathrm{~h}$, then aq. $\mathrm{HCl}$.

Only two studies have previously investigated the mechanism in detail for the silver-catalyzed dehydrogenation of alcohols. ${ }^{[11 c, 21]}$ In both cases, FTIR spectroscopy and labelling experiments were employed and silver was deposited on a heterogeneous support (alumina ${ }^{[11 c]}$ or silica ${ }^{[21]}$ ). The studies revealed a catalytic pathway where the alcohol is absorbed on the surface of the support, which is also responsible for abstracting the proton from the hydroxy group. ${ }^{[11 c, 21]}$ Silver then cleaves hydride from the alkoxide to form the carbonyl compound and silver hydride where the latter reacts with the abstracted proton to release hydrogen gas. ${ }^{[11 \mathrm{c}, 21]}$ A similar pathway can be envisioned in the present case where hydroxide at the surface of the silver nanoparticles is responsible for deprotonating the primary alcohol.

\section{Conclusions}

In summary, we have described a new protocol for the dehydrogenation of primary alcohols into carboxylic acids where a platinum group metal or a specially prepared metal complex is not required. A variety of benzylic and aliphatic alcohols undergo the transformation in the presence of $2.5 \%$ of $\mathrm{Ag}_{2} \mathrm{CO}_{3}$ and $2.5-$ 3 equiv. of $\mathrm{KOH}$ in refluxing mesitylene. The reaction is believed to proceed through the in situ formation of silver nanoparticles as the active catalyst responsible for the release of hydrogen gas.

\section{Experimental Section}

General Information: Mesitylene was dried by distillation from sodium. All solvents were of HPLC grade and were not further purified. Gas chromatography was performed on a Shimadzu GCMS-QP2010S instrument fitted with an Equity $5,30 \mathrm{~m} \times 0.25 \mathrm{~mm} \times 0.25 \mu \mathrm{m}$ column. The TEM image was obtained on a Zeiss EM10C transmission electron microscope operating at $100 \mathrm{kV}$. The XRD measurement was carried out on a Philips X'pert 1710 diffractometer (CuK radiation, $\lambda=0.154056 \mathrm{~nm}$ ) operating at $40 \mathrm{kV} / 30 \mathrm{~mA}$ over the $2 \theta$ range of $5^{\circ}-80^{\circ}$ at a scan rate of $0.02 \%$. NMR spectra were recorded on a Bruker Ascend 400 spectrometer. Chemical shifts were measured relative to the signals of residual DMSO- $d_{5}\left(\delta_{H}=2.50 \mathrm{ppm}\right)$ and DMSO- $d_{6}\left(\delta_{\mathrm{c}}=39.5 \mathrm{ppm}\right)$. The evolution of hydrogen gas was measured in the same way as described previously. ${ }^{[5 a]}$

General Procedure: A three neck Schlenk tube $(50 \mathrm{~mL})$ was charged with PVP (15 mg), $\mathrm{MnBr}_{2}(21.5 \mathrm{mg}, 0.1 \mathrm{mmol}), \mathrm{Ag}_{2} \mathrm{CO}_{3}(27.6 \mathrm{mg}, 0.1$ $\mathrm{mmol}$ ), $\mathrm{KOH}$ (560 mg, $10.0 \mathrm{mmol}$ for benzylic alcohols; $672 \mathrm{mg}, 12.0$ $\mathrm{mmol}$ for aliphatic alcohols) and a stir bar. A coldfinger was attached and the tube was evacuated and refilled three times with nitrogen. Mesitylene $(3 \mathrm{~mL})$ was added and the mixture stirred at room temperature for $5 \mathrm{~min}$ The tube was then placed in an oil bath and heated with a rate of $5{ }^{\circ} \mathrm{C} / \mathrm{min}$. At $50{ }^{\circ} \mathrm{C}$ the primary alcohol $(4 \mathrm{mmol})$ was added and heating the mixture with a rate of $5^{\circ} \mathrm{C} / \mathrm{min}$ continued until $165^{\circ} \mathrm{C}$. The reaction was monitored by GC until completion ( $8 \mathrm{~h}$ for benzylic alcohols; $20 \mathrm{~h}$ for aliphatic alcohols) and the Schlenk tube was then removed from the oil bath and cooled to room temperature. Water $(2 \mathrm{~mL})$ was added to dissolve the salts followed by $19 \%$ aqueous $\mathrm{HCl}(\sim 1 \mathrm{~mL}$ for benzylic alcohols; $2 \mathrm{~mL}$ for aliphatic alcohols) until $\mathrm{pH} 5-6$. The solution was washed with EtOAc $(5 \mathrm{~mL})$. The aqueous layer was acidified with $19 \%$ aqueous $\mathrm{HCl}$ to $\mathrm{pH} 1$ and then extracted with EtOAc $(3 \times 8 \mathrm{~mL})$. The combined organic layers were dried over $\mathrm{Na}_{2} \mathrm{SO}_{4}$ and concentrated in vacuo to give the corresponding acid which may be further purified by recrystallization.

Dehydrogenation of Benzyl Alcohol with Preformed Silver Nanoparticles: Following a literature protocol[16c] PVP (100 mg) was dissolved in ethylene glycol $(2 \mathrm{~mL})$ in a Schlenk tube under nitrogen. $\mathrm{AgNO}_{3}(68 \mathrm{mg}, 0.4 \mathrm{mmol})$ was added and the mixture was heated at a rate of $5{ }^{\circ} \mathrm{C} / \mathrm{min}$ to $120^{\circ} \mathrm{C}$ in an oil bath. After heating for $1 \mathrm{~h}$ at $120^{\circ} \mathrm{C}$ the tube was cooled to room temperature and acetone $(10 \mathrm{~mL})$ was added. Centrifugation and removal of the solvent left a black sticky precipitate which was washed with acetone $(2 \mathrm{~mL})$. The residue was transferred to another Schlenk tube and dried under vacuum. The tube was filled with nitrogen, and $\mathrm{KOH}$ (560 mg, $10.0 \mathrm{mmol}$ ) and mesitylene (3 $\mathrm{mL}$ ) were added. The mixture was heated as described above and benzyl alcohol $(0.41 \mathrm{~mL}, 4 \mathrm{mmol})$ was added at $50^{\circ} \mathrm{C}$. Nonane $(0.2 \mathrm{~mL})$ was added as an internal reference after heating at $165^{\circ} \mathrm{C}$ for $8 \mathrm{~h}$ and the mixture was quenched with $19 \%$ aqueous $\mathrm{HCl}$. The $\mathrm{GC}$ yield of benzoic acid was determined to be $91 \%$.

Benzoic acid:[4a] Table 1, entry 1. Isolated as white crystals after recrystallization from water in $92 \%$ yield $(450 \mathrm{mg}) .{ }^{1} \mathrm{H} \mathrm{NMR}(400 \mathrm{MHz}$, DMSO- $\left.d_{6}\right): \delta=7.50(\mathrm{t}, J=7.1 \mathrm{~Hz}, 2 \mathrm{H}), 7.62(\mathrm{t}, J=7.3 \mathrm{~Hz}, 1 \mathrm{H}), 7.95(\mathrm{~d}, J$ $=8.0 \mathrm{~Hz}, 2 \mathrm{H}), 12.94(\mathrm{~s}, \mathrm{OH}) \mathrm{ppm} .{ }^{13} \mathrm{C}$ NMR $\left(100 \mathrm{MHz}, \mathrm{DMSO}-d_{6}\right): \delta=$ 128.4, 129.1, 130.6, 132.7, 167.1 ppm. MS (El): $\mathrm{m} / z=122.05[\mathrm{M}]^{+}$.

p-Methylbenzoic acid:[5a] Table 1, entry 2. Isolated as a white solid after recrystallization from water/ethanol in $85 \%$ yield $(463 \mathrm{mg}) .{ }^{1} \mathrm{H}$ NMR (400 MHz, DMSO-d6): $\delta=2.35(\mathrm{~s}, 3 \mathrm{H}), 7.28(\mathrm{~d}, J=8.0 \mathrm{~Hz}, 2 \mathrm{H}), 7.83(\mathrm{~d}, J=$ $8.2 \mathrm{~Hz}, 2 \mathrm{H}), 12.77(\mathrm{~s}, \mathrm{OH}) \mathrm{ppm} .{ }^{13} \mathrm{C}$ NMR $\left(100 \mathrm{MHz}, \mathrm{DMSO}-d_{6}\right): \delta=21.4$, $128.3,129.4,129.6,143.3,167.6$ ppm. MS (El): $m / z=136.05\left[\mathrm{M}^{+}\right.$

p-(Trifluoromethyl)benzoic acid: ${ }^{[22]}$ Table 1, entry 3. Isolated as a white solid in $98 \%$ yield $(745 \mathrm{mg}) .{ }^{1} \mathrm{H}$ NMR (400 MHz, DMSO- $\left.d_{6}\right): \delta=7.74$ (d, J $=8.2 \mathrm{~Hz}, 2 \mathrm{H}), 8.09(\mathrm{~d}, J=8.1 \mathrm{~Hz}, 2 \mathrm{H}), 13.41(\mathrm{~s}, 1 \mathrm{H}) \mathrm{ppm} .{ }^{13} \mathrm{C}$ NMR $(100$ MHz, DMSO- $d_{6}$ ): $\delta=123.6$ (q, $J=272 \mathrm{~Hz}$ ), 125.3 (q, $J=4 \mathrm{~Hz}$ ), 130.0, 132.6 (q, $J=32 \mathrm{~Hz}), 134.6,166.2$ ppm. MS (El): $\mathrm{m} / z=189.90[\mathrm{M}]^{+}$.

p-Chlorobenzoic acid: ${ }^{[7]}$ Table 1 , entry 4 . Isolated as a white solid after recrystallization from water/ethanol in $86 \%$ yield $(539 \mathrm{mg}) .{ }^{1} \mathrm{H}$ NMR (400 MHz, DMSO- $\left.d_{6}\right): \delta=7.56(\mathrm{~d}, J=8.2 \mathrm{~Hz}, 2 \mathrm{H}), 7.94(\mathrm{~d}, J=8.2 \mathrm{~Hz}, 2 \mathrm{H})$ ppm. ${ }^{13} \mathrm{C}$ NMR $\left(100 \mathrm{MHz}, \mathrm{DMSO}-d_{6}\right): \delta=129.0,129.9,131.4,138.1$, 166.8 ppm. MS (El): $m / z=155.95[\mathrm{M}]^{+}$.

p-(Methoxycarbonyl)benzoic acid::23] Table 1, entry 7 . Isolated as a white solid after recrystallization from water/ethanol in $88 \%$ yield (634 mg). ${ }^{1} \mathrm{H}$ NMR (400 MHz, DMSO- $\left.d_{6}\right): \delta=3.86(\mathrm{~s}, 3 \mathrm{H}), 8.00-8.10(\mathrm{~m}, 4 \mathrm{H})$, $13.33(\mathrm{~s}, 1 \mathrm{H}) \mathrm{ppm} .{ }^{13} \mathrm{C}$ NMR (100 MHz, DMSO-d $): \delta=52.7,129.6$, 129.8, 133.4, 135.1, 165.9, 166.8 ppm. MS (El): $\mathrm{m} / z=179.95[\mathrm{M}]^{+}$.

p-Methoxybenzoic acid: ${ }^{[4 a]}$ Table 1 , entry 8 . Isolated as a white solid after recrystallization from water/ethanol in $75 \%$ yield $(454 \mathrm{mg}) .{ }^{1} \mathrm{H}$ NMR (400 MHz, DMSO-d6): $\delta=3.82(\mathrm{~s}, 3 \mathrm{H}), 7.01(\mathrm{~d}, J=8.9 \mathrm{~Hz}, 2 \mathrm{H}), 7.90$ (d, $J=8.8 \mathrm{~Hz}, 2 \mathrm{H}), 12.61$ (s, OH) ppm. ${ }^{13} \mathrm{C}$ NMR (100 MHz, DMSO- $\left.d_{6}\right): \delta=$ $55.2,113.6,122.8,131.2,162.7,166.8 \mathrm{ppm}$. MS (El): $\mathrm{m} / z=152.05[\mathrm{M}]^{+}$. p-(Benzyloxy)benzoic acid:[24] Table 1, entry 9. Isolated as a white solid after recrystallization from water/ethanol in $71 \%$ yield $(649 \mathrm{mg}) .{ }^{1} \mathrm{H}$ NMR (400 MHz, DMSO-d $\left.d_{6}\right): \delta=5.17(\mathrm{~s}, 2 \mathrm{H}), 7.09(\mathrm{~d}, J=8.8 \mathrm{~Hz}, 2 \mathrm{H}), 7.33(\mathrm{t}, J$ $=7.1 \mathrm{~Hz}, 1 \mathrm{H}), 7.39(\mathrm{t}, J=7.3 \mathrm{~Hz}, 2 \mathrm{H}), 7.46(\mathrm{~d}, J=7.1 \mathrm{~Hz}, 2 \mathrm{H}), 7.90(\mathrm{~d}, J$ $=8.8 \mathrm{~Hz}, 2 \mathrm{H}), 12.64(\mathrm{~s}, \mathrm{OH}) \mathrm{ppm} .{ }^{13} \mathrm{C}$ NMR $\left(100 \mathrm{MHz}, \mathrm{DMSO}-d_{6}\right): \delta=$ 
69.7, 114.8, 123.4, 128.0, 128.2, 128.7, 131.6, 136.7, 162.2, $167.2 \mathrm{ppm}$. MS (EI): $m / z=227.00[\mathrm{M}]^{+}$

[1,1']-Biphenyl-4-carboxylic acid:[22] Table 1, entry 10. Isolated as a white solid after recrystallization from water/ethanol in $76 \%$ yield $(600$ $\mathrm{mg}) .{ }^{1} \mathrm{H}$ NMR $\left(400 \mathrm{MHz}\right.$, DMSO- $\left.d_{6}\right): \delta=7.41(\mathrm{t}, J=7.3 \mathrm{~Hz}, 1 \mathrm{H}), 7.49$ (t, $J$ $=7.5 \mathrm{~Hz}, 2 \mathrm{H}), 7.72(\mathrm{~d}, J=7.3 \mathrm{~Hz}, 2 \mathrm{H}), 7.79(\mathrm{~d}, J=8.3 \mathrm{~Hz}, 2 \mathrm{H}), 8.03(\mathrm{~d}, J$ $=8.3 \mathrm{~Hz}, 2 \mathrm{H}), 13.03(\mathrm{~s}, \mathrm{OH}) \mathrm{ppm} .{ }^{13} \mathrm{C}$ NMR $\left(100 \mathrm{MHz}\right.$, DMSO-d $\left.\mathrm{d}_{6}\right): \delta=$ 126.6, 126.8, 128.1, 128.9, 129.5, 129.8, 138.9, 144.1, 167.0 ppm. MS $(\mathrm{El}): \mathrm{m} / \mathrm{z}=197.95[\mathrm{M}]^{+}$.

p-(Methylthio)benzoic acid:[5a] Table 1, entry 11 . Isolated as a white solid after recrystallization from water/ethanol in $65 \%$ yield $(435 \mathrm{mg}) .{ }^{1} \mathrm{H}$ NMR $\left(400 \mathrm{MHz}\right.$, DMSO- $\left.d_{6}\right): \delta=2.57(\mathrm{~s}, 3 \mathrm{H}), 7.38(\mathrm{~d}, J=8.5 \mathrm{~Hz}, 2 \mathrm{H})$, $7.91(\mathrm{~d}, J=8.5 \mathrm{~Hz}, 2 \mathrm{H}), 12.90$ (s, OH) ppm. ${ }^{13} \mathrm{C}$ NMR (100 MHz, DMSO$\left.d_{6}\right): \delta=13.6,124.5,126.3,129.3,144.4,166.7 \mathrm{ppm}$. MS $(\mathrm{El}): \mathrm{m} / z=$ $167.95[\mathrm{M}]^{+}$

2,4,6-Trimethylbenzoic acid:[22] Table 1, entry 12. Isolated as a white solid after recrystallization from water/ethanol in $58 \%$ yield $(374 \mathrm{mg}) .{ }^{1} \mathrm{H}$ NMR (400 MHz, DMSO-d $\left.d_{6}\right): \delta=2.52(\mathrm{~s}, 3 \mathrm{H}), 2.57$ (s, 6H), $7.15(\mathrm{~s}, 2 \mathrm{H})$, $13.27(\mathrm{~s}, 1 \mathrm{H}) \mathrm{ppm} .{ }^{13} \mathrm{C}$ NMR $\left(100 \mathrm{MHz}\right.$, DMSO- $\left.d_{6}\right): \delta=19.3,20.6,128.0$, 132.6, 133.7, 138.0, 170.9 ppm. MS (EI): $\mathrm{m} / z=164.00[\mathrm{M}]^{+}$

2-Naphthoic acid:[22] Table 1, entry 14. Isolated as a light brownish solid after recrystallization from water/ethanol in $73 \%$ yield $(500 \mathrm{mg}) .{ }^{1} \mathrm{H}$ NMR $\left(400 \mathrm{MHz}, \mathrm{DMSO}-d_{6}\right): \delta=7.61(\mathrm{t}, J=7.0 \mathrm{~Hz}, 1 \mathrm{H}), 7.66(\mathrm{t}, J=6.8 \mathrm{~Hz}, 1 \mathrm{H})$ 7.98-8.00 (m, 3H), $8.11(\mathrm{~d}, J=8.1 \mathrm{~Hz}, 1 \mathrm{H}), 8.61(\mathrm{~s}, 1 \mathrm{H}), 13.03(\mathrm{~s}, \mathrm{OH})$ ppm. ${ }^{13} \mathrm{C}$ NMR $\left(100 \mathrm{MHz}\right.$, DMSO-d $\left.d_{6}\right): \delta=124.8,126.4,127.2,127.7$, $127.8,127.9,128.9,130.1,131.7,134.5,167.0 \mathrm{ppm}$. MS (El): $\mathrm{m} / \mathrm{z}=$ $171.95[\mathrm{M}]^{+}$

Decanoic acid:[5a] Table 2, entry 1. Isolated as a white solid in $71 \%$ yield (492 mg). ${ }^{1} \mathrm{H}$ NMR (400 MHz, DMSO- $\left.d_{6}\right): \delta=0.85$ (t, $J=6.7 \mathrm{~Hz}, 3 \mathrm{H}$ ), $1.20-1.30(\mathrm{~m}, 12 \mathrm{H}), 1.48$ (t, $J=7.1 \mathrm{~Hz}, 2 \mathrm{H}), 2.18$ (t, $J=7.4 \mathrm{~Hz}, 2 \mathrm{H}$ ), $11.95(\mathrm{~s}, \mathrm{OH}) \mathrm{ppm} .{ }^{13} \mathrm{C}$ NMR $(100 \mathrm{MHz}$, DMSO-d $): \delta=13.9,22.1,24.5$ 28.6, 28.7, 28.8, 28.9, 31.3, 33.7, 174.4 ppm. MS (El): $\mathrm{m} / z=172.00$ [M] $^{+}$ Cyclopentanecarboxylic acid:[5a] Table 2, entry 2 . Isolated as a yellow oil in $79 \%$ yield $(361 \mathrm{mg}) .{ }^{1} \mathrm{H}$ NMR $\left(400 \mathrm{MHz}\right.$, DMSO- $\left.d_{6}\right): \delta=1.21-2.07$ $(\mathrm{m}, 8 \mathrm{H}), 2.60$ (td, $J=7.9,3.2 \mathrm{~Hz}, 1 \mathrm{H}), 11.87(\mathrm{~s}, \mathrm{OH}) \mathrm{ppm} .{ }^{13} \mathrm{C}$ NMR $(100$ MHz, DMSO- $\left.d_{6}\right): \delta=25.9,30.0,43.7,177.8 \mathrm{ppm}$. MS (EI): $\mathrm{m} / \mathrm{z}=114.00$ $[\mathrm{M}]^{+}$

Cyclohexylacetic acid:[25] Table 2, entry 3 . Isolated as a white solid in $59 \%$ yield $(334 \mathrm{mg}) .{ }^{1} \mathrm{H}$ NMR $\left(400 \mathrm{MHz}\right.$, DMSO- $\left.\mathrm{d}_{6}\right): \delta=0.69-0.99(\mathrm{~m}$, $2 \mathrm{H}), 1.01-1.31(\mathrm{~m}, 3 \mathrm{H}), 1.38-1.74(\mathrm{~m}, 6 \mathrm{H}), 2.07(\mathrm{~d}, J=6.7 \mathrm{~Hz}, 2 \mathrm{H})$, 11.96 (s, $1 \mathrm{H}) \mathrm{ppm} .{ }^{13} \mathrm{C}$ NMR $(100 \mathrm{MHz}$, DMSO-d6): $\delta=25.6,25.7,32.4$, 34.2, 41.6, $173.7 \mathrm{ppm}$. MS (EI): $\mathrm{m} / z=141.95[\mathrm{M}]^{+}$.

3-Phenylpropanoic acid:[5c] Table 2, entry 4. Isolated as a yellow oil in $91 \%$ yield $(548 \mathrm{mg}) .{ }^{1} \mathrm{H}$ NMR $\left(400 \mathrm{MHz}\right.$, DMSO- $\left.d_{6}\right): \delta=2.54(\mathrm{t}, J=7.7$ $\mathrm{Hz}, 2 \mathrm{H}$ ), 2.83 (t, $J=7.6 \mathrm{~Hz}, 2 \mathrm{H}), 7.19-7.29(\mathrm{~m}, 5 \mathrm{H}), 12.16$ (s, OH) ppm. ${ }^{13} \mathrm{C}$ NMR $\left(100 \mathrm{MHz}\right.$, DMSO- $\left.d_{6}\right): \delta=30.4,35.3,126.0,128.3,128.3$, 141.0, $173.9 \mathrm{ppm}$. MS (EI): $\mathrm{m} / z=150.05[\mathrm{M}]^{+}$

Cyclohex-3-enecarboxylic acid:[26] Table 2, entry 6. Isolated as a yellow oil in $78 \%$ yield $(393 \mathrm{mg})$. ${ }^{1} \mathrm{H}$ NMR $(400 \mathrm{MHz}$, DMSO-d6): $\delta=$ 1.37-1.61 (m, $1 \mathrm{H}), 1.88(\mathrm{dt}, J=12.7,4.2 \mathrm{~Hz}, 1 \mathrm{H}), 1.94-2.19(\mathrm{~m}, 4 \mathrm{H})$, 2.40 (ddt, $J=12.0,5.9,3.3 \mathrm{~Hz}, 1 \mathrm{H}$ ), 5.61 (d, $J=11.1 \mathrm{~Hz}, 2 \mathrm{H}$ ), 12.09 (s, $\mathrm{OH})$ ppm. ${ }^{13} \mathrm{C}$ NMR $\left(100 \mathrm{MHz}\right.$, DMSO-d $\left.d_{6}\right): \delta=24.1,24.8,27.2,38.5$, $125.5,126.6,176.5 \mathrm{ppm}$. MS (El): $\mathrm{m} / z=126.00\left[\mathrm{M}^{+}\right.$.

(1S,2S,5S)-6,6-Dimethylbicyclo[3.1.1] heptane-2-carboxylic acid:[5a] Table 2, entry 7 . Isolated as a yellow-brown oil in $78 \%$ yield $(525 \mathrm{mg})$. $[\alpha]$ $\mathrm{D}^{20}=+1.9\left(c=1.0\right.$, EtOAc). ${ }^{1} \mathrm{H}$ NMR $\left(400 \mathrm{MHz}\right.$, DMSO- $\left.d_{6}\right): \delta=0.82(\mathrm{~s}, 3 \mathrm{H})$ $1.18(\mathrm{~s}, 3 \mathrm{H}), 1.39(\mathrm{~d}, J=9.5 \mathrm{~Hz}, 1 \mathrm{H}), 1.62(\mathrm{ddt}, J=14.4,6.5,4.5 \mathrm{~Hz}, 1 \mathrm{H})$ 1.76 (ddd, $J=9.3,6.4,2.6 \mathrm{~Hz}, 2 \mathrm{H}$ ), 1.82 (tt, $J=5.4,2.5 \mathrm{~Hz}, 1 \mathrm{H}$ ), 1.92 $2.02(\mathrm{~m}, 1 \mathrm{H}), 2.06(\mathrm{dt}, J=5.6,1.5 \mathrm{~Hz}, 2 \mathrm{H}), 2.74(\mathrm{t}, J=8.7 \mathrm{~Hz}, 1 \mathrm{H}), 8.44$ (s, OH) ppm. ${ }^{13} \mathrm{C}$ NMR $(100 \mathrm{MHz}$, DMSO-d $): \delta=16.3,20.1,23.6,23.9$, 26.3, 38.7, 39.7, 40.6, 43.4, $177.1 \mathrm{ppm}$. MS (EI): $\mathrm{m} / z=168.00[\mathrm{M}]^{+}$.

\section{Acknowledgements}

We thank the Villum Fonden for financial support (grant 12380).

Keywords: alcohols $\cdot$ carboxylic acids $\cdot$ dehydrogenation $•$ nanoparticles $\cdot$ silver

[1] (a) C. Gunanathan, D. Milstein, Science 2013, 341, 1229712. (b) G. E. Dobereiner, R. H. Crabtree, Chem. Rev. 2010, 110, 681-703.

[2] E. Balaraman, E. Khaskin, G. Leitus, D. Milstein, Nat. Chem. 2013, 5, 122-125.

[3] (a) L. Zhang, D. H. Nguyen, G. Raffa, X. Trivelli, F. Capet, S. Desset, S. Paul, F. Dumeignil, R. M. Grauvin, ChemSusChem 2016, 9, 1413-1423. (b) J.-H. Choi, L. E. Heim, M. Ahrens, M. H. G. Prechtl, Dalton Trans. 2014, 43, 17248-17254. (c) P. Sponholz, D. Mellmann, C. Cordes, P. G. Alsabeh, B. Li, Y. Li, M. Nielsen, H. Junge, P. Dixneuf, M. Beller, ChemSusChem 2014, 7, 2419-2422.

[4] (a) E. W. Dahl, T. Louis-Goff, N. K. Szymczak, Chem. Commun. 2017 53, 2287-2289. (b) Z. Dai, Q. Luo, X. Meng, R. Li, J. Zhang, T. Peng, J. Organomet. Chem. 2017, 830, 11-18.

[5] (a) C. Santilli, I. S. Makarov, P. Fristrup, R. Madsen, J. Org. Chem. 2016, 81, 9931-9938. (b) D. Ventura-Espinosa, C. Vicent, M. Baya, J. A. Mata, Catal. Sci. Technol. 2016, 6, 8024-8035. (c) J. Malineni, H. Keul, M. Möller, Dalton Trans. 2015, 44, 17409-17414.

[6] A. Sarbajna, I. Dutta, P. Daw, S. Dinda, S. M. W. Rahaman, A. Sarkar, J. K. Bera, ACS Catal. 2017, 7, 2786-2790.

[7] X. Wang, C. Wang, Y. Liu, J. Xiao, Green Chem. 2016, 18, 4605-4610.

[8] Y. Sawama, K. Morita, S. Asai, M. Kozawa, S. Tadokoro, J. Nakajima Y. Monguchi, H. Sajiki, Adv. Synth. Catal. 2015, 357, 1205-1210.

[9] (a) I. S. Makarov, R. Madsen, J. Org. Chem. 2013, 78, 6593-6598. (b) I. S. Makarov, P. Fristrup, R. Madsen, Chem. Eur. J. 2012, 18, 15683-15692. (c) A. Maggi, R. Madsen, Organometallics 2012, 31, $451-455$.

[10] (a) A. Mukherjee, A. Nerush, G. Leitus, L. J. W. Shimon, Y. Ben David N. A. E. Jalapa, D. Milstein, J. Am. Chem. Soc. 2016, 138, 4298-4301. (b) G. Jaiswal, V. G. Landge, D. Jagadeesan, E. Balaraman, Green Chem. 2016, 18, 3232-3238. (c) G. Zhang, S. K. Hanson, Org. Lett. 2013, 15, 650-653. (d) J. M. Pérez, R. Cano, M. Yus, D. J. Ramón, Eur. J. Org. Chem. 2012, 4548-4554. (e) H. Liu, G.-K. Chuah, S. Jaenicke, J. Catal. 2012, 292, 130-137.

[11] (a) K. Shimizu, K. Ohshima, A. Satsuma, Chem. Eur. J. 2009, 15, 9977-9980; (b) K. Shimizu, R. Sato, A. Satsuma, Angew. Chem. Int. Ed. 2009, 48, 3982-3986; Angew. Chem. 2009, 121, 4042-4046. (c) K. Shimizu, K. Sugino, K. Sawabe, A. Satsuma, Chem. Eur. J. 2009, 15, 2341-2351

[12] (a) M. Hosseini-Sarvari, T. Ataee-Kachouei, F. Moeini, Mater. Res. Bull. 2015, 72, 98-105. (b) A. Bayat, M. Shakourian-Fard, N. Ehyaei, M. M. Hashemi, RSC Adv. 2015, 5, 22503-22509. (c) T. Mitsudome, Y. Mikami, H. Funai, T. Mizugaki, K. Jitsukawa, K. Kaneda, Angew. Chem. Int. Ed. 2008, 47, 138-141; Angew. Chem. 2008, 120, 144-147.

[13] (a) S. Chakraborty, U. Gellrich, Y. Diskin-Posner, G. Leitus, L. Avram D. Milstein, Angew. Chem. Int. Ed. 2017, 56, 4229-4233; Angew. Chem. 2017, 129, 4293-4297. (b) N. Deibl, R. Kempe, Angew. Chem. Int. Ed. 2017, 56, 1663-1666; Angew. Chem. 2017, 129, 1685-1688. (c) M. Mastalir, M. Glatz, N. Gorgas, B. Stöger, E. Pittenauer, G Allmaier, L. F. Veiros, K. Kirchner, Chem. Eur. J. 2016, 22, 12316-12320. (d) S. Elangovan, J. Neumann, J.-P. Sortais, K. Junge, C. Darcel, M. Beller, Nat. Commun. 2016, 7: 12641.

[14] X.-Y. Dong, Z.-W. Gao, K.-F. Yang, W.-Q. Zhang, L.-W. Xu, Catal. Sci. Technol. 2015, 5, 2554-2574.

[15] G. Merga, R. Wilson, G. Lynn, B. H. Milosavljevic, D. Meisel, J. Phys. Chem. C 2007, 111, 12220-12226.

[16] (a) A. Slistan-Grijalva, R. Herrera-Urbina, J. F. Rivas-Silva, M. ÁvalosBorja, F. F. Castillón-Barraza, A. Posada-Amarillas, Physica E 2005, 25, 438-448, (b) M. Zheng, M. Gu, Y. Jin, G. Jin, Mater. Res. Bull. 2001, 
36, 853-859. (c) P.-Y.Silvert, R. Herrera-Urbina, N. Duvauchelle, V. Vijayakrishnan, K. T. Elhsissen, J. Mater. Chem. 1996, 6, 573-577.

[17] Other additives were also investigated for stabilizing the nanoparticles. However, only $20-44 \%$ yield were obtained when using 2 hydroxypyridine, 2,2'-dipyridine-6,6'-diol, $N, N$-dimethylethylenediamine, triethylenetetramine, 2-pyridinemethanamine or di(2-picolyl)amine instead of PVP.

[18] (a) G. M. Whitesides, M. Hackett, R. L. Brainard, J.-P. P. M. Lavalleye, A. F. Sowinski, A. N. Izumi, S. S. Moore, D. W. Brown, E. M. Staudt, Organometallics 1985, 4, 1819-1830. (b) D. R. Anton, R. H. Crabtree, Organometallics 1983, 2, 855-859.

[19] For $\mathrm{Ag} / \mathrm{Al}_{2} \mathrm{O}_{3}$-catalyzed reduction of nitrobenzenes in the presence of alcohols, see: K. Shimizu, K. Shimura, M. Nishimura, A. Satsuma, ChemCatChem 2011, 3, 1755-1758.
[20] A longer reaction time for aliphatic alcohols as compared to benzylic alcohols was also employed in the previous dehydrogenations catalyzed by $\left[\mathrm{RuCl}_{2}(\mathrm{I} / \mathrm{Pr})(p\right.$-cymene $\left.)\right]$ and $\mathrm{Pd} / \mathrm{C}$; see refs $5 \mathrm{a}$ and 8 .

[21] V. L. Sushkevich, I. I. Ivanova, E. Taarning, ChemSusChem 2013, 5, 2367-2373.

[22] R. Zheng, Q. Zhou, H. Gu, H. Jiang, J. Wu, Z. Jin, D. Han, G. Dai, R. Chen, Tetrahedron Lett. 2014, 55, 5671-5675.

[23] Y. Makida, E. Marelli, A. M. Z. Slawin, S. P. Nolan, Chem. Commun. 2014, 50, 8010-8013.

[24] C. Sun, Y. Li, A. Shi, J. Zhang, Y. Li, M. Zhao, L. Zhang, H. Zheng, Y. Meng, H. Ding, H. Song, Med. Chem. Commun. 2015, 6, 1137-1142.

[25] B. El Ali, H. Alper, J. Org. Chem. 1993, 58, 3595-3596.

[26] J. Zhao, C. Mück-Lichtenfeld, A. Studer, Adv. Synth. Catal. 2013, 355, 1098-1106. 
Entry for the Table of Contents (Please choose one layout)

Layout 1:

\section{FULL PAPER}

Text for Table of Contents

Layout 2:

\section{FULL PAPER}

((Insert TOC Graphic here: $\max$. width: $5.5 \mathrm{~cm}$; max. height: $5.0 \mathrm{~cm}$ ))

Author(s), Corresponding Author(s)*

Page No. - Page No.

Title

$$
\begin{gathered}
2.5 \% \mathrm{Ag}_{2} \mathrm{CO}_{3} \\
-\mathrm{CH}_{2} \mathrm{OH} \\
\begin{array}{c}
2.5 \% \mathrm{MnBr}_{2}, \mathrm{PVP} \\
\mathrm{KOH} \text {, mesitylene } \\
\text { then } \mathrm{HCl}
\end{array}
\end{gathered} \stackrel{\mathrm{R}^{-\mathrm{C}}-\mathrm{OH}}{\mathrm{O}}+2 \mathrm{H}_{2}
$$

No platinum group metals: The acceptorless dehydrogenation of primary alcohols into carboxylic acids is achieved with silver carbonate as the precatalyst. The reaction can be applied to a variety of alcohols and is believed to be mediated by in situ formed silver nanoparticles.
Hajar Golshadi Ghalehshahi, Robert Madsen*

Page No. - Page No.

Silver-Catalyzed Dehydrogenative Synthesis of Carboxylic Acids from Primary Alcohols 